\title{
Disrupted Expression of Circadian Clock Genes in Patients with Bronchial Asthma [Corrigendum]
}

Chen HC, Chen YC, Wang TN, et al. J Asthma Allergy. 2021;14:371-380.

Page 372, Patients and Methods, Patients, Healthy Subjects, and Samples section, line 7, the text "IRB
No. 201801642B0A3C501" should read "IRB No. 2018 01642B0A3".

The authors apologize for this error.

\section{Publish your work in this journal}

The Journal of Asthma and Allergy is an international, peer-reviewed open-access journal publishing original research, reports, editorials and commentaries on the following topics: Asthma; Pulmonary physiology; Asthma related clinical health; Clinical immunology and the immunological basis of disease; Pharmacological interventions and new therapies. The manuscript management system is completely online and includes a very quick and fair peer-review system, which is all easy to use. Visit http://www.dovepress.com/testimonials.php to read real quotes from published authors. 